\title{
The Art of Goodbye: Putting Your Legal and Financial Affairs in Order ${ }^{1}$
}

\author{
Brenda C. Williams²
}

\section{Introduction}

This document is part of a series which addresses end-oflife concerns, entitled The Art of Goodbye.

Making final legal and financial decisions can often be an uncomfortable and complex process. This publication is designed to help you consider your specific circumstances and gather the information you will need when talking with the professionals who will work to carry out your wishes.

\section{Ten Steps for Putting Your Legal and Financial Affairs in Order}

This publication is not a listing of specific procedures; rather, it is a guide meant to help you identify considerations and tasks that must be addressed and completed. Please note that you can start with any step. The ultimate goal is to complete all of them.

\section{- Organize financial and family information}

The object of this step is to gather all your information into one safe place where it can be easily accessed when needed. This information includes an inventory of your assets, such as personal property, investments, retirement and savings accounts, insurance policies, real estate holdings, and business interests.

The way you choose to arrange this information is up to you. There are in-hand publications, workbooks, and electronic resources. If you want to use an online option, remember to use a secure and reliable electronic resource to protect your information. For more information, see EDIS document HE988, Family Records (http://edis.ifas.ufl.edu/ he988).

Understand that this step will take time to complete. It is important to try to list everything. You can then decide how you would like to transfer these assets: through gifts, will, or trusts. This process will also help you decide what type(s) of power of attorney may be necessary.

\section{- Complete advance directives}

The term "advance directives" broadly refers to documents that allow you to state the actions you want to be taken when it comes to your care and identify the person who should make those decisions if you become unable to make such decisions yourself. In Florida, this includes two documents: a living will and a designation of health care surrogate. Under Florida law, both should be in the form of a written document. Specific information and a sample form can be found at the website of The Florida Bar: http:// www.floridabar.org. You can complete these documents by following the guidelines provided.

Please remember that these documents do not give someone else the authority to deal with your financial matters, such as the payment of medical bills. Preparation of durable

1. This document is FCS3341, one of a series of the Department of Family, Youth and Community Sciences, UF/IFAS Extension. Original publication date January 2018. Visit the EDIS website at http://edis.ifas.ufl.edu.

2. Brenda C. Williams, professor emerita, UF/IFAS Extension Alachua County; UF/IFAS Extension, Gainesville, FL 32611.

The Institute of Food and Agricultural Sciences (IFAS) is an Equal Opportunity Institution authorized to provide research, educational information and other services only to individuals and institutions that function with non-discrimination with respect to race, creed, color, religion, age, disability, sex, sexual orientation, marital status, national origin, political opinions or affiliations. For more information on obtaining other UF/IFAS Extension publications, contact your county's UF/IFAS Extension office. 
power of attorney documents is usually suggested to convey authority to handle your legal and financial affairs.

\section{- Communicate your health care wishes}

Before, during, and after the completion of your advance directives, you should communicate your health care preferences to your health care surrogate and discuss these preferences with your family members. These conversations are often difficult. For more information about opening the lines of communication and following through with health care providers and loved ones, see the other publications in The Art of Goodbye series: http://edis.ifas.ufl.edu/topic_series_eole. Being clear about your preferences helps prevent confusion and potential conflicts.

\section{- Review and update beneficiary designations}

Using the information gathered from your inventory of assets, review the beneficiaries of your insurance policies, pensions, IRAs, and other accounts. Review these documents annually to confirm they still accurately reflect your wishes and circumstances. Tax season is a good time for this review because you will already be in the process of accessing and compiling information about your accounts. You may need to make changes to these documents in the event of deaths, divorces, marriages, births, and other major life events.

\section{- Write a letter of last instruction}

This is an informal and very helpful document that you develop on your own to assist your loved ones. The letter may express a variety of your wishes after your death and provide instructions for any funeral arrangements you want made or have already made. For more information about planning final arrangements, see EDIS document FY1466, The Art of Goodbye: Planning Final Arrangements (http:// edis.ifas.ufl.edu/fy1466). You may wish to write and include your own obituary in this letter.

This letter is an opportunity to provide essential information to your loved ones. You can say as little or as much as you like. It can explain how and/or why you have made certain arrangements and address any other topics you wish to discuss.

It is important to have this letter available immediately after your death. A family member, friend, or attorney may keep this document. A copy may be kept in a safe deposit box, but the original must be more readily available.

\section{- Select your professional legal and financial team}

There are many kinds of financial professionals, such as financial planners, investment specialists, accountants, attorneys, insurance agents, and bankers. Understanding the roles, expertise, and credentials of these individuals can help you select the most appropriate person or team for your specific financial needs. Seeking professional advice incurs fees and expenses. Choose the members of your team carefully. Credentials alone do not ensure a financial professional's competence, but they provide a starting point to compare skills and assumed knowledge in given areas (Williams, Douglas, Gillen, \& Spence, 2013). For more information on navigating this process, see EDIS document FY1370, Women and Money: Unique Issues-Selecting Your Financial Professional Team (http://edis.ifas.ufl.edu/fy1370). The information in the aforementioned publication is applicable to men as well.

Note: The June 2015 ruling by the United States Supreme Court that legalizes same-sex marriage should encourage affected individuals to seek legal assistance in preparing appropriate documents.

\section{- Evaluate the use of life insurance in your financial planning}

The proceeds from a life insurance policy are often sources of funds for medical bills and other expenses incurred at the end of life. Understanding how the ownership and designated beneficiaries of policies will affect your estate planning is important. Your policies that list your estate as the beneficiary will include the funds in your estate settlement process. Policies owned by others on your life will not be included in the value of the estate. Your legal and financial team will assist you in this area.

\section{- Have durable power of attorney documents prepared}

A durable power of attorney must be executed to transfer authority over your financial affairs. A financial durable power of attorney designates an individual to have this power to make financial decisions on your behalf. You may designate different individuals to perform different tasks in separate power of attorney documents. It is important to choose someone whom you trust to make responsible decisions with your wishes and best interests in mind. Consider appointing one person to make financial decisions and another person to make health decisions.

Remember that all power of attorney authority ends upon your passing. Other documents, such as a will or trust, are necessary to maintain actions that are in accordance with your wishes. 


\section{- Have a will prepared and sign it}

Estate planning objectives will differ among families due to a variety of factors, such as differences in assets, value judgments, culture, personal preference, marital status, and number of children. Even though there are many estate planning tools, a will is considered to be the cornerstone of most estate plans. A will is a written legal document that takes effect at the time of death and communicates your wishes about the way you want to distribute your personal and financial assets. It is used to administer the estate, transfer real property ownership (real estate is usually done by title), and make provisions for the care of minor or dependent children. A properly drawn will simplifies estate administration, minimizes costs, and decreases family conflict over property distribution.

Your estate is everything you own. It includes your home, automobile, jewelry, bank accounts, investments, retirement plans, furnishings, and other belongings. Your estate will include probate and non-probate property. Non-probate property is distributed according to deed, title, or contract. Probate property is distributed according to your will or state law in the absence of a will.

States often have different legal requirements for wills. The state in which you reside, or your domicile, determines your will's validity. If you have moved to Florida from another state, you will want to have your will reviewed by a local estate planning attorney.

For more information on the requirements of a valid Florida will, visit the website of The Florida Bar: http:// www.floridabar.org.

Remember to only sign the original will and keep it where it can be easily accessed upon your death. Do not keep the original will in a safe deposit box.

\section{- Consider creating a revocable living trust}

A trust is similar to a will in the sense that it discusses asset distribution and management after your passing. It differs from a will because it allows you to designate someone to manage your assets while you are still living and select successor trustees to manage the trust after your death. This entails transferring ownership of property to the trust (funding the trust) and designating a trustee, who can be you or a trusted loved one, to manage it. It is important to choose someone whom you trust to act in your best interest. Your attorney can inform you about the various types of trusts and the way each type will affect estate taxes and gift taxes, and provide protection for your assets.

\section{Make an action plan and get started}

After reading this publication and considering your own specific circumstances, you are ready to get started.

- Identify the documents you already have.

- Determine which documents need updating.

- Review the beneficiaries listed on all documents.

- Schedule appointments with your professional legal and financial team.

- Develop a strategy to communicate your health care preferences to others.

Do not let all these tasks overwhelm you. Break the tasks into smaller parts and set goals to complete them within a reasonable time frame. Remind yourself that with each item you complete, you come closer to knowing your wishes will be honored.

\section{References}

The Florida Bar. (2017a). Consumer pamphlet: Do you have a will? The Florida Bar. Accessed on December 20, 2017. https://www.floridabar.org/public/consumer/pamphlet011/

The Florida Bar. (2017b). Consumer pamphlet: Florida Power of Attorney. The Florida Bar. Accessed on December 20, 2017. https://www.floridabar.org/public/consumer/ pamphlet13/

The Florida Bar. (2017c). Living wills, health care surrogates, and advanced directives. The Florida Bar. Accessed on December 20, 2017. https://www.floridabar.org/public/ consumer/consumer003/

The Florida Bar. (2017d). Consumer pamphlet: Probate in Florida. The Florida Bar. Accessed on December 20, 2017. https://www.floridabar.org/public/consumer/pamphlet026/

The Florida Bar. (2017e). Consumer pamphlet: the revocable trust in Florida. The Florida Bar. Accessed on December 20, 2017. https://www.floridabar.org/public/ consumer/pamphlet028/

Gillen, M., Mitchell, V., \& Turner, J. (2012). Estate Planning. FY446. Gainesville: University of Florida Institute of Food and Agricultural Sciences. http://edis.ifas.ufl.edu/fy446 
Turner, J., \& Gillen, M. (2011). Estate Planning: Getting Started. FY538. Gainesville: University of Florida Institute of Food and Agricultural Sciences. http://edis.ifas.ufl.edu/ fy 538

Turner, J., \& Gillen, M. (2011). Estate Planning: Preparing a Letter of Last Instructions. FY537. Gainesville: University of Florida Institute of Food and Agricultural Sciences. http:// edis.ifas.ufl.edu/fy537

Gillen, M., \& Turner, J. (2012). Estate Planning: Your Will. FY540. Gainesville: University of Florida Institute of Food and Agricultural Sciences. http://edis.ifas.ufl.edu/fy540

Williams, B. C., Seamon, B., \& Gillen, M. (2013). Family Records. HE988. Gainesville: University of Florida Institute of Food and Agricultural Sciences. http://edis.ifas.ufl.edu/ he988

Williams, B. C., Douglass, D., Gillen, M., \& Spence, L. (2013). Women and Money: Unique Issues-Selecting Your Financial Professional Team. FY1370. Gainesville: University of Florida Institute of Food and Agricultural Sciences. http://edis.ifas.ufl.edu/fy1370 